\title{
Design of Marine Protected Areas on high seas and territorial waters of Rockall Bank
}

\author{
Jason M. Hall-Spencer ${ }^{1,6, *}$, Mark Tasker ${ }^{2,6}{ }^{,}$Marta Soffker $^{1}$, Sabine Christiansen ${ }^{3,6}$, \\ Stuart Rogers ${ }^{4}$, Maria Campbell ${ }^{1}$, Kjartan Hoydal ${ }^{5}$ \\ ${ }^{1}$ Marine Institute, Marine Biology and Ecology Research Centre, University of Plymouth, Plymouth, PL4 8AA, UK \\ ${ }^{2}$ Joint Nature Conservation Committee, Dunnet House, 7 Thistle Place, Aberdeen, AB10 1UZ, UK \\ ${ }^{3}$ WWF North-East Atlantic Programme, Magdeburger Str. 17, 20457 Hamburg, Germany \\ ${ }^{4}$ The Centre for Environment, Fisheries and Aquaculture Science, Pakefield Road, Lowestoft, Suffolk, NR33 0HT, UK \\ ${ }^{5}$ North East Atlantic Fisheries Commission, 22 Berners Street, London, W1T 3DY, UK \\ ${ }^{6}$ ICES Working Group on Deep-water Ecology
}

\begin{abstract}
Fisheries closures are rapidly being developed to protect vulnerable marine ecosystems worldwide. Satellite monitoring of fishing vessel activity indicates that these closures can work effectively with good compliance by international fleets even in remote areas. Here we summarise how remote fisheries closures were designed to protect Lophelia pertusa habitat in a region of the NE Atlantic that straddles the EU fishing zone and the high seas. We show how scientific records, fishers' knowledge and surveillance data on fishing activity can be combined to provide a powerful tool for the design of Marine Protected Areas.
\end{abstract}

KEY WORDS: Lophelia pertusa - MPA · Fisheries - Offshore - Marine Protected Area - NE Atlantic · Vessel monitoring system $\cdot$ VMS

Resale or republication not permitted without written consent of the publisher

\section{INTRODUCTION}

The past few years have seen rapid development in the use of fisheries closures to protect deep-water coral habitats from destructive fishing practices throughout the North Atlantic. The world's first deep-water coral protected area came into effect in 1984, but did not prevent trawling damage to Oculina varicosa reefs off the Atlantic coast of Florida due to lack of enforcement (Reed et al. 2005). Surveys in the late 1990s revealed that bottom trawling and long-lining was also causing widespread and long-term damage to more northern coral communities on both sides of the Atlantic (Jones \& Willison 2001, Hall-Spencer et al. 2002). This met with rapid responses by the authorities, with the establishment of cold-water coral protected areas first in Scandanavia and Canada (Fosså et al. 2002, Mortensen et al. 2005) followed by closures in EU waters, the USA and Iceland. The first areas in the Atlantic high seas to be closed to protect deep-water habitats entered into force on 1 January 2005 and were recommended by the North East Atlantic Fisheries Commission (NEAFC), followed by closures in the NW Atlantic by the Northwest Atlantic Fisheries Organization (NAFO) from 1 January 2007 (Table 1). Satellite monitoring of fishing vessel activity has indicated that these closures can work effectively with good compliance by international fleets even in remote areas such as the Darwin Mounds, a coral-rich area $180 \mathrm{~km}$ off the NW coast of Scotland (Davies et al. 2007).

Here we summarise how deep-water Lophelia pertusa habitats were selected for closure on Rockall Bank (see ICES 2002, 2006, 2007a). The Bank lies to the west of Scotland in the NE Atlantic and straddles the boundary between the fishing zone managed by the EU and the high seas, where fishing is managed by NEAFC. The Bank supports important fisheries for haddock and other shallower water species on the upper slopes and top of the bank, together with deeper-water species such as monkfish and blue ling on the lower slopes. 
Table 1. Areas closed to bottom trawl fishing in the North Atlantic to protect deep- and/or cold-water habitats (adapted from ICES 2007a). Note Gilkinson \& Edinger (2009) provide an update on Canadian closures since 2007. NEAFC: North East Atlantic Fisheries Commission; NAFO: Northwest Atlantic Fisheries Organization

\begin{tabular}{|c|c|c|}
\hline Closed area & Region & Year closed \\
\hline Oculina Bank & USA & 1984 \\
\hline Sula Reef & Norway & 1999 \\
\hline Iverryggen Reef & Norway & 2000 \\
\hline Selligrunnen Reef & Norway & 2000 \\
\hline Sacken reef & EU (Sweden) & 2001 \\
\hline Spiran reef (degraded) & EU (Sweden) & 2001 \\
\hline Vadero reef (degraded) & EU (Sweden) & 2001 \\
\hline Northeast Channel & Canada & 2002 \\
\hline Tisler Reef & Norway & 2003 \\
\hline Fjellknausene Reef & Norway & 2003 \\
\hline Røst Reef & Norway & 2003 \\
\hline The Gully & Canada & 2004 \\
\hline Stone Fence & Canada & 2004 \\
\hline Darwin Mounds & EU $(\mathrm{UK})$ & 2004 \\
\hline $\begin{array}{l}\text { Azores, Madeira, } \\
\text { Canary Islands }\end{array}$ & EU (Spain/Portugal) & 2004 \\
\hline $\begin{array}{l}\text { Reykjanes Ridge } \\
\text { (part of) }\end{array}$ & NEAFC & 2005 \\
\hline Hekate Seamounts & NEAFC & 2005 \\
\hline Faraday Seamounts & NEAFC & 2005 \\
\hline Altair Seamounts & NEAFC & 2005 \\
\hline Antialtair Seamounts & NEAFC & 2005 \\
\hline Oceanographer Canyon & USA & 2005 \\
\hline Lydonia Canyon & USA & 2005 \\
\hline Hornafjardardjúp & Iceland & 2006 \\
\hline Skaftárdjúp & Iceland & 2006 \\
\hline Reynisdjúp & Iceland & 2006 \\
\hline Orphan Knoll & NAFO & 2007 \\
\hline $\begin{array}{l}\text { Newfoundland } \\
\text { Seamounts }\end{array}$ & NAFO & 2007 \\
\hline Corner Seamount & NAFO & 2007 \\
\hline $\begin{array}{l}\text { New England } \\
\text { Seamounts }\end{array}$ & NAFO & 2007 \\
\hline Hatton Bank & NEAFC & 2007 \\
\hline NW Rockall Bank & NEAFC/EU (UK) & 2007 \\
\hline W Rockall Mounds & NEAFC & 2007 \\
\hline Logachev Mounds & NEAFC/EU (Eire) & 2007 \\
\hline NW Porcupine Bank & EU (Eire) & proposed \\
\hline $\begin{array}{l}\text { Hovland Mound } \\
\text { Province }\end{array}$ & EU (Eire) & proposed \\
\hline SW Porcupine Bank & EU (Eire) & proposed \\
\hline $\begin{array}{l}\text { Belgica Mound } \\
\text { Province }\end{array}$ & EU (Eire) & proposed \\
\hline
\end{tabular}

\section{METHODS}

Based on evidence presented by the World Wildlife Foundation, the Convention for the Protection of the Marine Environment in the North Atlantic (OSPAR) communicated to NEAFC its concern about the conservation of Lophelia pertusa reefs on the Bank. NEAFC then requested the International Council for the Exploration of the Sea (ICES) to indicate appropriate bound- aries of any closure of areas where cold-water corals are affected by fishing activities. Three sources of information were used by the ICES Working Group on Deep Water Ecosystems (WGDEC) to identify such boundaries. These were: (1) records in the scientific literature and elsewhere of the occurrence of L. pertusa; (2) the knowledge of fishers using the Bank on the distribution of Lophelia; and (3) records of fishing activity derived from satellite-based vessel monitoring systems (VMS).

Each of these sources had their advantages and disadvantages. Scientific records may be very old, and historical records of coral occurrence may now be inaccurate, as may be the geographical locations of records due to poor position fixing or if the data are from long dredge hauls (Hall-Spencer et al. 2007). In contrast, fishers' knowledge is recent and therefore may be more 'believable' to the fishing industry, but may not be complete or fully accurate. VMS records showing the location of trawling activity are generally comprehensive and unbiased, but there are several reasons for an area of the seabed to remain unfished; notwithstanding the presence of net-damaging corals, other seabed obstructions may exist or it may be too deep for trawling to take place. These sources could not necessarily be relied upon individually to identify suitable closure areas, but when used together provided a powerful tool indicating where such closed areas should be established.

VMS positions were provided by NEAFC, the Irish Navy and the UK Department of Environment, Food and Rural Affairs for 2005, the most recent year of comprehensive available information on the distribution of fishing fleets in the area. VMS data were filtered to remove non-trawling activity by only including vessels travelling between 1.5 and 4.5 knots. Note that this filter did not remove all pelagic trawling tracks from the plot and may include some vessels travelling slowly in the area, but not fishing. These records were combined with data on coral distribution provided by WGDEC reports, and new information on Lophelia distribution from surveys carried out by the UK Government in 2005 and 2006 (Davies et al. 2006, Howell et al. 2009), a Fisheries Research Services (FRS) monkfish survey in November 2006 (FRS unpubl. data) and data from the EU HERMES programme (van Duyl \& Duineveld 2005). The final analysis (Fig. 1) combined information on the spatial distribution of coral records and data describing fleet distribution to select potential sites for

Fig. 1. North East Atlantic Fisheries Commission/EU closures (hatched) around Rockall off Scotland and Ireland in 2007. (a) Deep-sea scleractinian areas noted by fishers (black shading) and (b) scientific records with overlay of filtered vessel monitoring system (VMS) tracks for 2005 showing the patchy distribution of fished areas around Rockall Bank 

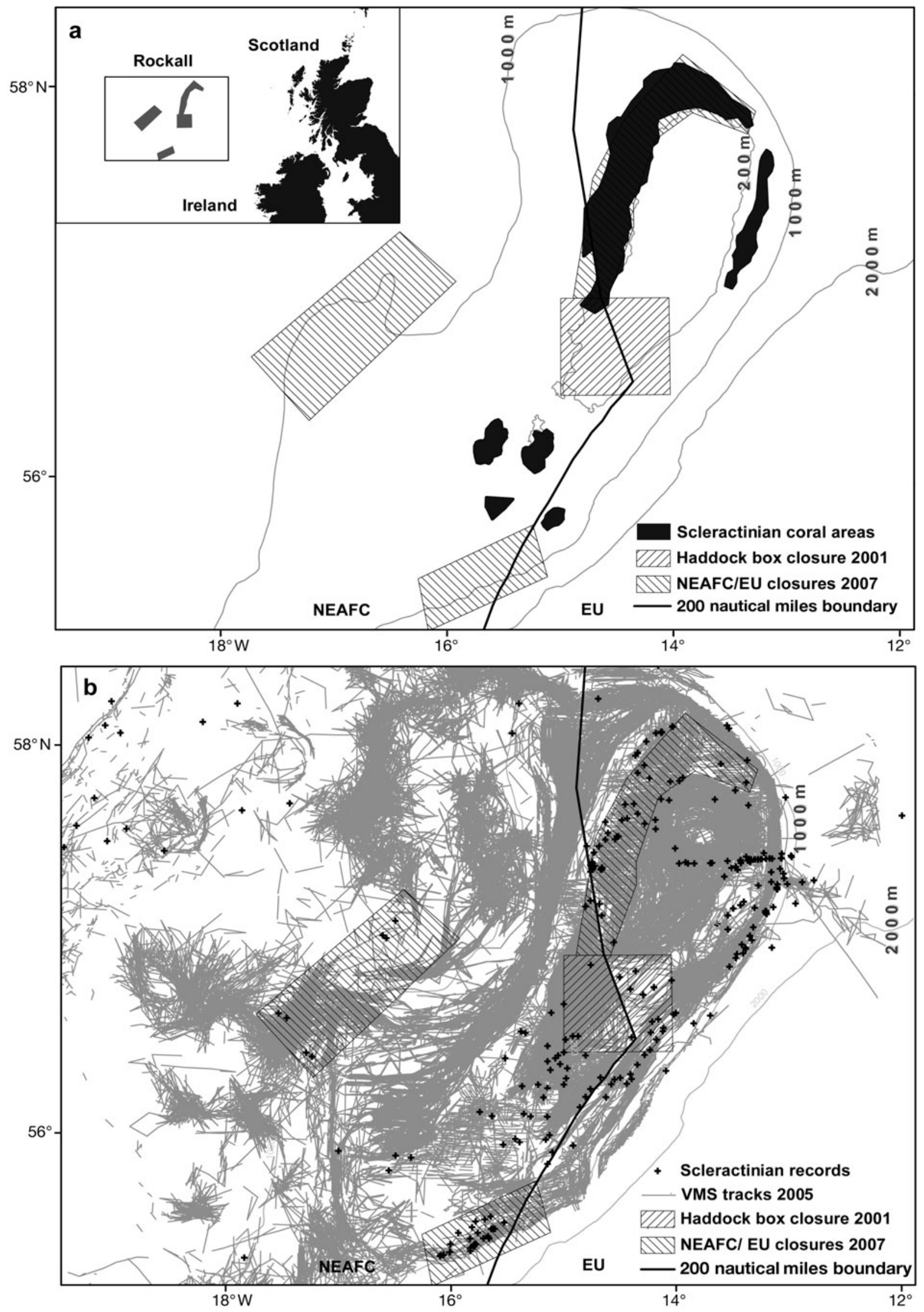
closure where the conservation benefit of closures was maximal and the displacement effect on fishing was minimal.

\section{RESULTS AND DISCUSSION}

Following ICES advice, areas of Rockall Bank in NEAFC- and EU-controlled waters were closed to fishing effective from March 2007 (ICES 2007a). Fig. 1 shows the North West Rockall, Logachev Mounds and West Rockall Mounds areas that were closed to protect coral habitat in 2007, in addition to an area that was closed to protect haddock stocks in 2001 which has the additional benefit of helping protect benthic habitats.

The process of designing and enforcing a network of offshore Marine Protected Areas is ongoing and has made significant progress in recent years. A new tranche of deep-water coral closures has been proposed within the Irish EEZ, also based on a combination of scientific surveys, fishers' knowledge and VMS (ICES 2007b). Further challenges to designing an ecologically robust network of closures remain, such as the need for an increased understanding of cold-water coral food webs and of larval transport to and from proposed closures, which could be tackled using molecular approaches (Le Goff-Vitry et al. 2004, van Oevelen et al. 2009). Effective surveillance and enforcement are critical to the protection of coral in these areas, which will be helped by VMS records which include data on the gear in use and vessel activity. Boundaries will also need to be designed to account for gears used and the frequency of transit.

Acknowledgements. This work was funded by the Esmée Fairbairn Foundation DC-UK project (www.deepseaconservation.org) and contributes to the EC-funded Framework 7 project Knowledge-based Sustainable Management for Europe's Seas (KnowSeas-226675.

\section{LITERATURE CITED}

Davies AJ, Narayanaswamy BE, Hughes DJ, Roberts JM (2006) An introduction to the benthic ecology of the Rockall-Hatton Area (SEA 7). Report for the Department of Trade and Industry. Available at www.offshoresea.org.uk/consultations/SEA_7/SEA7_Benthos_SRSL.pdf

> Davies AJ, Roberts JM, Hall-Spencer JM (2007) Preserving deep-sea natural heritage: emerging issues in offshore conservation and management. Biol Conserv 138:299-312 Fosså JH, Mortensen PB, Furevik DM (2002) The deep-water

Submitted: March 2, 2009; Accepted: July 22, 2009 coral Lophelia pertusa in Norwegian waters: distribution and fishery impacts. Hydrobiologia 471:1-12

Gilkinson KD, Edinger EN (eds) (2009) The ecology of deepsea corals in Newfoundland and Labrador waters: biogeography, life history, biogeochemistry, and role as critical habitat. Can Tech Rep Fish Aquat Sci 2830

> Hall-Spencer JM, Allain V, Fosså JH (2002) Trawling damage to Northeast Atlantic ancient coral reefs. Proc R Soc Lond B Biol Sci 269:507-511

Hall-Spencer JM, Rogers A, Davies J, Foggo A (2007) Historical deep-sea coral distribution on seamount, oceanic island and continental shelf-slope habitats in the NE Atlantic. In: George RY, Cairns SD (eds) Conservation and adaptive management of seamount and deep-sea coral ecosystems. Rosenstiel School of Marine and Atmospheric Science, University of Miami, Miami, p 135-146

Howell KL, Davies JS, Jacobs C, Narayanaswamy BE (2009) Broadscale survey of the habitats of Rockall Bank, and mapping of Annex I 'reef' habitat. JNCC Report No. 422, Joint Nature Conservation Committee, Peterborough

ICES (2002) Study group on mapping the occurrence of cold water corals. ICES CM 2002/ACE:05, ICES, Copenhagen

ICES (2006) Report of the working group on deep-water ecology. ICES CM 2006/ACE:04, ICES, Copenhagen

ICES (2007a) Report of the working group on deep-water ecology. ICES CM 2007/ACE:01 Ref. LRC, ICES, Copenhagen

ICES (2007b) Report of the ad hoc group for western Irish Natura sites. ICES CM 2007/ACE:06, ICES, Copenhagen

Jones DP, Willison JHM (2001) The role of the Canadian Ocean Habitat Protection Society in deep-sea coral education and conservation advocacy in Nova Scotia. In: Willison JHM, Hall J, Gass SE, Kenchington ELR, Butler M, Doherty P (eds) Proc First Int Symp Deep-Sea Corals. Ecology Action Centre and Nova Scotia Museum, Halifax, p 166-174

Le Goff-Vitry MC, Pybus OG, Rogers AD (2004) Genetic structure of the deep-sea coral Lophelia pertusa in the North East Atlantic revealed by microsatellites and ITS sequences. Mol Ecol 13:537-549

Mortensen PB, Buhl-Mortensen L, Gordon DC, Fader GBJ, McKeown DL, Fenton DG (2005) Effects of fisheries on deep-water gorgonian corals in the Northeast Channel, Nova Scotia (Canada). Am Fish Soc Symp 41:369-382

Reed JK, Shepard AN, Koenig C, Sanlon KN, Gilmore RG (2005) Mapping, habitat characterization, and fish surveys of the deep-water Oculina coral reef Marine Protected Area: a review of historical and current research. In: Freiwald A, Roberts M (eds) Cold-water corals and ecosystems. Springer, Berlin/Heidelberg, p 443-465

van Duyl FC, Duineveld GCA (2005) Biodiversity, ecosystem functioning and food web complexity of deep water coral reefs in the NE Atlantic (Rockall Bank and Porcupine Bank). BIOSYS-HERMES 2005 Cruise Report Cruise 64PE 238. Royal Netherlands Institute for Sea Research, Texel

Van Oevelen D, Duineveld G, Lavaleye M, Mienis F, Soetaert K, Heip CHR (2009) The cold-water coral community as a hot spot for carbon cycling on continental margins: a foodweb analysis from Rockall Bank (northeast Atlantic). Limnol Oeanogr 54:1829-1844

Proofs received from author(s): October 26, 2009 